\title{
The Development of Vocational and Technical Secondary Education in Turkey*
}

\section{Subhan EKȘioĞLU**}

\section{Mehmet TAŞPINAR $^{* * *}$}

\begin{abstract}
This study investigates the historical development of vocational and technical secondary education in Turkey, and addresses the conducting projects in order to enhance vocational and technical education. The project approaches the development of vocational and technical secondary education from pre-republican era until the present by examining literature using collecting method. Until 18th century, it was seen that vocational education appeared in mentor-protégé fashion, and 18th century onwards, foundation of vocational and technical education institutions which merely corresponded to today's understanding of education was observed. Development of vocational and technical education gained importance with the republican era, and critical studies have been done to contribute to the quantitative and qualitative incline of technical education in spite of the arrest points throughout the years. Studies regarding the development of vocational and technical education have been drastically escalated especially after 1970 with OSANOR, METGE, MTEM, MEGEP, and IKMEP projects. However, vocational and technical education has still not reached to its desired degree due to various reasons.
\end{abstract}

Keywords: Vocational and technical education, secondary education, educational history, curriculum.

\footnotetext{
* This study was produced from the doctoral dissertation of the first author.

** Orcid id: http://orcid.org/0000-0002-5471-627X, Assist. Prof. Dr., Sakarya University, Educational Sciences, Curriculumn and Instruction, eksioglu@sakarya.edu.tr *** Orcid id: http://orcid.org/0000-0003-3152-0300, Prof. Dr., Gazi University, Educational Sciences, Curriculumn and Instruction, mehmettaspinar@gazi.edu.tr
} 


\section{INTRODUCTION}

In today's world, the most important indicator of the advancement and development of countries is to have well-trained and qualified workforce. With qualified and educated workforce, it is possible to compete in economic field and to increase production quality. Therefore, in order to keep up with the rapidly developing and changing information society, it has become compulsory to train individuals who have critical thinking and problem solving skills, can follow innovations and developments and have knowledge and skills in different fields (Altın, 2007). The vocational and technical education systems of the countries undertake the task of training qualified workforce and prepare individuals for the business world and further education levels. Particularly at secondary education level, these functions are consistently integrated and programs with integrity in terms of personal and professional development are attempted to be implemented (Şahin, \& Fındık, 2008: 74).

In order to carry out vocational and technical education to the desired extent and to train qualified workforce, scientific developments and changes need to be followed and reflected to education. Therefore, vocational education and training needs to be reorganized according to the changing conditions over the years. From this point of view, the development of Turkey's vocational and technical secondary education in historical process is studied and the studies performed on the development of vocational technical education are discussed in this study. It is believed that the results obtained from this study will contribute to national education employees, academicians and all parties involved in vocational and technical secondary education.

\section{METHOD}

In this study, compilation method was used as a research method. The compilation method allows the analysis of the studies carried out in a specific field and subject, thus the information in the literature is reproduced by synthesis. The aim of the compilation studies that review the existing studies in the literature and combine old and new interpretations in the light of reviewing or reveal completely new interpretations is to summarize the thoughts and approaches of other researchers and to create a new synthesis (Herdman, 2006).

In this study it is aimed to demonstrate the researches performed in order to develop vocational and technical secondary education which is being practised in today's Turkey as well as the historical development of vocational and technical education in Turkey generally. In this context the development of vocational and technical education in Turkey is attempted to be explained in the historical process, and studies have been tried to be summarized by scanning the literature. 


\section{VOCATIONAL AND TECHNICAL EDUCATION}

Alkan, Doğan and Sezgin (2001: 3) defined vocational and technical education as the process of developing the individual in a balanced way in mental, emotional, social, economic and personal terms by providing the individual with the knowledge, skills and practical abilities required by a particular profession for individual and social life. Apart from providing people with the ability to adapt to society, vocational and technical education can be considered as a type of education that will enable people to gain the knowledge and skills for a profession in which they will make their living. From this point of view, it can be easily stated that vocational and technical education not only provides individuals with the knowledge and skills related to work, but it also ensures the cooperation of all institutions and organizations in the society and thus it is a training system that trains qualified workforce based on not only formal vocational trainings, but also non-formal trainings, trainings in the workplaces as well as schools and cooperation (Celep, 2006).

The main purpose of vocational and technical education is to train qualified workforce. Achieving this objective depends on the economic, social and cultural conditions of the countries. At this point, the largest contribution to vocational and technical education is provided by vocational and technical secondary education institutions. Along with the aims of general secondary education, vocational and technical secondary education institutions are educational institutions that prepare students for higher education and train them as workforce in the fields of work and occupation (Altın, 2007: 35).

\section{Vocational and Technical Secondary Education in Turkey}

Vocational and technical secondary schools in Turkey are divided into two as vocational high schools and technical high schools. Vocational high schools are institutions that are open to all who completed the primary education and want to get vocational education. Technical high schools are the schools in which students who successfully complete the first year of vocational high school and want to receive technical education (Şahin, \& Findık, 2008). When the development of these educational institutions in the historical process is examined, there is no formal educational institution in the pre-republic period that deals with craft and vocational education until the 18th century. Craft and vocational education has been done by being side by side with craftsmen and artisans depending on the master-apprentice relationship. The earliest known vocational education organization in the pre-republican period was the Ahi-order organized by Ahi Evran in the 13th century (Kazu, 2002). It was foreseen that education should continue throughout the life in this organization which aimed to educate the people both professionally and artistically as well as develop moral attitudes and values, while it was ensured that the participants of the organization get education and training which both provided them personal development and granted the skills necessary for them to reach the level of mastership in their profession and to open their own workplaces. (Kazu, 2002; Sahinkesen, 1985; Yilmaz, 1996). This institution, which continued its existence under the names of Lonca (Guild) and Gedik (Mastership) in the following years, started 
to lose its function towards the end of the 17th century and came to an end with the opening of vocational education institutions in the 18th century (Şahin, \& Findık, 2008).

The first formal education institutions, which started to be opened in the 18th century and form the basis of today's vocational and technical schools, were "correctional facilities" which were opened to provide shelter and vocational education for orphans. During this period, "correctional facilities for girls" and a commercial school were opened in order to meet the housing and educational needs of orphaned girls (Şahin, \& Findık, 2008; Yılmaz, 1996).

Together with the modernization movement, various colleges were founded especially to train engineers and doctors needed by the army and craft schools were established to meet the need for military equipment within the country and the need in technical personnel required for the maintenance of existing equipment (Alkan, Doğan, \& Sezgin, 2001). After the publication of the Tanzimat Decree, it was proposed by the statesmen to open vocational and technical schools in order to meet the need of trained workforce as an element of economic development and accordingly, vocational schools and programs that could be implemented in these schools were declared in the Statute of Ministry of Education which was issued in 1857. In this period, various vocational and technical education institutions such as Military Veterinary School, Agricultural Education School, Forestry School, Maâdin (Mines) School, Mektebi Maarif-i Adliye (Civil Servant School) and Language School were opened considering the regional needs and the management, staff and financial support of these institutions were tried to be met locally (Akyüz, 2001; Alkan, Doğan, \& Sezgin, 2001; Kazu, 2002; Şahin, \& Findık, 2008). These vocational and technical education institutions opened during the Tanzimat period established the foundations of vocational and technical education schools opened during the republican period.

In the post-republic period, vocational and technical education was structured in three different models. First, the School-Centred Model in which full-time sole school education was conducted and secondly, "Business-Centred Model", in which students were trained full-time in enterprises, were put into practise. Finally, the "Dual System Model" based on school-business cooperation in which the students are at school one or two days a week and at workplace on the other days aiming to show students the links between theory and practice as well as introduce new technologies to them, and therefore to develop school and business cooperation. (Adıgüzel, \& Berk, 2009; MEB, 2012; Şahinkesen, 1992). Especially in the first years of the republic, this system was endeavoured to be established by performing studies for the coordination among ministries. However, it is seen that the needs of enterprises were ignored when vocational and technical education programs were organized between 1940 and 1960 . Since the 1970s, the cooperation between schools and industry has started to develop again with the contributions of the chambers of commerce and industry as well as the enterprises. 
Vocational and technical secondary education institutions are the educational institutions that are obliged to train students as workforce according to the needs of their professional fields and at the same time prepare them for higher education in accordance with the aims of general secondary education. In accordance with the suggestions of the experts such as John Devey, Kuhne and Ömer Buyse who were invited to Turkey in the early years of republic in order to improve vocational and technical secondary education institutions which were from pre-republican period and inadequate in terms of quantity and quality, it was planned to open secondary vocational schools for those who would continue their work life after primary school and establish institutions that would meet the technical workforce needs, therefore; Vocational and Technical Education General Directorate was established in 1933 (Doğan, 1995; Akyüz, 2001; Kazu, 2002, Yllmaz, 1996). After the establishment of this directorate, the Girls Technical Teacher School was opened in the 1934-1935 academic year in order to meet the needs of teachers for the schools established as well as being established and the Male Technical Teacher School was opened in the academic year of 1937-1938. During this period, "Evening Craft Schools for Boys" were opened in Ankara, Bursa and Istanbul. Since the 1942-1943 academic year, Craft Schools for Boys have been transformed into Craft Institutes for Boys. During the same period, many institutions for boys and girls, construction institutions and business schools were opened. After the 1950s, Trade and Tourism Higher Teacher Education School and Industrial Crafts Higher Teacher Education School joined to the teacher schools (Akyüz, 2001; Yllmaz, 1996). Between 1968 and 1970 technician schools were opened in order to train technical semi-skilled workers and these schools were later transformed into technical high schools. In the same period, the craft institutes were named as industrial vocational high schools. After 1980, the Ministry of National Education underwent a new restructuring and as a result, Anatolian vocational high schools and Anatolian technical high schools were opened in order to train technical personnel with foreign language skills. As a result of the change which made the duration of compulsory primary education eight years, the secondary school part of vocational high schools was closed after 1997-1998. Starting from the 2001-2002 academic year, vocational and technical secondary education institutions, as well as vocational and technical education centres giving certificates at secondary level have started to operate (Akyüz, 2001; Kazu, 2002). General Directorate of Technical Education for Boys, General Directorate of Technical Education for Girls, General Directorate of Commerce and Tourism Education, Department of Health Affairs and Vocational and Technical Education Organization structured as Apprenticeship and Vocational and Technical Education Development and Dissemination Department until 2011 were gathered under the roof of General Directorate of Vocational and Technical Education established by the Decree Law No. 652 on the Organization and Duties of the Ministry of National Education (MTEGM, 2018).

In various periods, studies were carried out to strengthen vocational and technical education with the decisions taken in development plans, government programs and National Education councils. In the 7th Five-Year Development Plan covering the years 
1996-2000, it was stated that vocational and technical education should be made flexible between formal and non-formal education in a way that would allow internal and external transfers at every stage and a system change should be made for the transition to modular education. In the 8th Development Plan covering the years 2001-2005, the necessity of determining occupational standards was especially emphasized and it was stated that cooperation with the sector should be established in every occupation field in order to determine these standards correctly. In the 9th Development Plan covering the years 2007-2013, it was emphasized that modular education should be started and a professional qualification system based on examination and certification should be established (MEB, 2010). In the 10th Development Plan covering the years 2014-2018, it was stated that the national qualification framework should be established and the education and training programs should be updated in accordance with the occupational standards. In this context, it was stated that diploma and certification systems with national and international validity would be developed. In addition, it was emphasized that vocational and technical education should be structured in a way to ensure the integrity between secondary and higher education and it should be based on practice (Ministry of Development, 2013).

The points that were emphasized in the National Education councils regarding vocational and technical education could be summarized as follows: In the 15th National Education Council in 1996, it was stated that a common core program should be established in order to facilitate transitions between programs and new arrangements should be made in order to facilitate internal and external transfers. Additionally, it was emphasized that the regulation to ensure this in vocational and technical education was modular education. In the 16th National Education Council in 1999, it was stated that vocational and technical education programs should be organized according to the modular approach and developed based on business analysis (MEB, 2010b).

In the 17th National Education Council in 2006, it was emphasized that the fields of vocational and technical education students should be determined again according to the course weights, and the students who graduated from these institutions should be provided with additional points in the transition to higher education institutions which are the continuation of the vocational field they graduated from and school administrators, professional chambers, local governments, public and private employers, written and visual media should cooperate in order to popularize vocational and technical education and students who choose vocational and technical education should be supported economically and socially. In addition, it was stated that private education institutions should provide vocational and technical education as well as services in the fields of non-formal education (MEB, 2006). In the 18th National Education Council in 2010, the subject of teacher training was discussed and it was stated that the need for teachers in vocational and technical institutions should be met with the pedagogical formation for the students of tourism faculty, art and design faculty, technology faculty and in order to meet the need for teachers in child development and education field, a new department should be opened in the faculty of 
health sciences. In the 18th National Education Council, it was emphasized that the workshops in vocational and technical secondary schools should be organized in accordance with the modular system, and it was stated that the social security rights of the students doing skills training in enterprises should be improved in order to increase the demand for vocational and technical secondary education. In addition to these, it was stated that additional points should be given to the students getting education in vocational and technical secondary education institutions during the transition to higher education when placing students in higher education institutions related to their fields (MEB, 2010c). In the 19th National Education Council, decisions such as updating the curriculum, the qualifications of the teachers and school administrators, ensuring the safety of the school, and equalizing the hours for the salaries of the branch teachers and vocational teachers were made. In addition, it was proposed to establish a National Education Academy in order to carry out the professional development as well as research and development activities of teachers (MEB, 2012; MEB, 2014).

When the government programs from the foundation of the Republic to the present day are examined, it is seen that statements about vocational and technical education are included occasionally. 22 of the 61 government programs directly addressed vocational technical education and announced the planned work to improve vocational and technical education. In the first government programs, it was emphasized that all individuals who completed primary education should be directed to vocational and technical secondary education institutions instead of going to a secondary education institution for higher education. It was stated in the government programs until 1960 that the main purpose of vocational and technical secondary education institutions was to train qualified workforce necessary for the labour market and that efforts were made to expand these institutions. In the post-1960 government programs, it was emphasized that the needs of the labour market will be taken into consideration in the opening of vocational and technical education institutions. In the post-1980 government programs, it was stated that priority was given to vocational and technical education and worked to draw attention to vocational and technical education (www.tbmm.gov.tr/kutuphane).

Carrying vocational and technical education to the world standards and determining vocational standards for this, preparing internationally recognized diplomas and certificates as well as designing modular vocational and technical education programs which will allow the internal and external mobility of the students can be stated as the common points of development plans, National Education councils and government programs (Mutlu, \& Akaya, 2006).

With the law no. 4702 adopted in year 2001, the secondary education system was reorganized by making the system more vocational and technical education oriented. Some of the innovations introduced by Law No. 4702 were: It was planned to design new programs, which were prepared in a flexible way that would prepare students for life and higher education and allow internal and external transfers. In addition, it was decided to establish vocational and technical education centres that could offer formal and non-formal education together. Additionally, a compensation program was 
organized within the scope of this law and it was planned to give vocational high school diploma to assistant masters, masters and general high school graduates who successfully completed this compensation program. With this law, it was stated that students who have completed vocational and technical secondary education could apply to vocational schools which are the continuation of the vocational and technical education program they completed without examination (Kazu, 2002; MEB 2010b, MEB, 2014).

Secondary schools were re-opened after the compulsory education's duration was increased to 12 years and rearranged as $4+4+4$ after the 2012-2013 academic year. However, the reopening of secondary schools did not enable vocational and technical education to start at the second level of this system. Vocational and technical education starts again from 9th grade which means it starts at high school. In the 9th grades of vocational and technical high schools, the curriculums that are applied in general high schools are included, and the vocational programs are implemented starting from the 10 th grade.

\section{The studies for the development of vocational and technical education in Turkey}

Vocational and technical education is the teaching of knowledge and skills for the training of qualified personnel for the professions needed in all areas of life (Özçiftçi, Göloğlu, \& Kadı, 2004: 216). In today's world where rapidly developing and renewed technologies are used, it is the most important duty of vocational and technical education institutions to train the workforce needed by countries with up to date and valid information. A vocational and technical education that does not have the necessary infrastructure and knowledge to accomplish this task will be difficult to survive both within the country and in the international market. For this reason, when structuring vocational and technical education, professions which are up to date and can create employment area should be studied properly and the qualifications that can be accepted in the world regarding these professions should be demonstrated and the content of vocational and technical education and the methods, techniques as well as tools to be used in this education should be selected in the most appropriate way (Gömleksiz, 2010).

From this point of view, preparing the students for the labour market, creating a system that evaluates all aspects of their academic and professional development and implementing the plans in which education and job opportunities are arranged in a balanced way should be aimed in vocational and technical education. However, when the status of vocational and technical education in Turkey examined, the problems that prevent the realization of these objectives can be listed as follows:

- Inability to provide sufficient guidance to the students, inability to direct them to the programs appropriate for their interests and abilities, and therefore making choice without knowing much about their profession, 
- The needs of national, local and business world are not taken into consideration in the preparation of programs for vocational and technical education and accordingly, the need for qualified workforce in various business fields cannot be met.

- The schools and workplaces do not work in a coordinated manner and therefore the education given in schools cannot create the workforce which the labour market expects.

- Inability to measure the occupational competence of students.

- Inability to implement educational programs in accordance with national and international standards (Kazu, 2002; Gömleksiz, 2010).

When these problems are considered briefly, it is seen that students are directed to schools by ignoring their interests and abilities and consequently, they try to turn towards a profession especially at university level as a result of wrong or incomplete practices in vocational and technical secondary education, Vocational and technical education programs should be arranged in a way that will involve the occupations that are valid in today's world, meet the regional and local needs and provide internal and external transfer opportunities for the students in order to train vocational and technical secondary education students as intermediate staff needed by the market. Starting from this idea, in order to raise the quality of the workforce and increase the employment opportunities in all business areas vocational training system has been being developed in Turkey for a long time (Gold, 2007). Vocational and technical education has been rearranged many times in line with the political and economic developments in the historical process (Adıgüzel and Berk, 2009: 221). Various practices including project based and legal regulations focused on the development and enhancement of vocational and technical education in Turkey in different time periods has been done by Ministry of Education. The first work aimed at changing and improving vocational and technical education started with the "School-Industry Collaborative Education Project which was carried out in the late 1970s. The School-Industry Collaborative Education (OSANOR) project was implemented jointly by the Ministry of National Education and Ankara University, Faculty of Educational Sciences between 1978 and 1980. Within the scope of this project, an industrial vocational high school was chosen as a test school in each cities of Adana, Bursa, Istanbul and İzmir. The aim of this project is to develop a system that can be carried out jointly by schools and industry in order to educate the qualified workforce needed in the country by considering the interests and abilities of individuals (Akhun, 1987). The number of schools was later increased to 23 in the OSANOR project, which was planned to be implemented in four selected schools from four provinces. Studies were carried out to determine the local needs with the beginning of this project aiming the cooperation of schools and industry in meeting vocational and technical education needs of the individuals. In addition, it was ensured that employers and employees participated in the planning of vocational and technical education with trainers and thus educators and business owners and employees recognized each other (Doğan, 1984). After the OSANOR project, especially 
following the introduction of apprenticeship and vocational education Law No. 3308 in 1986, projects and studies aimed at vocational and technical education accelerated with the contributions of non-governmental organizations, public institutions, ministry of national education, universities and various experts. According to this law, arrangements have been made regarding the insurance of apprentices, payment of insurance premiums by the state and the apprentice fees. At the same time, with this law, students receiving vocational and technical education were ensured to spend $2 / 3$ of their teaching time in enterprises (Eroğlu, 1999). Other efforts to change and improve vocational and technical education can be summarized as follows:

METGE: "Vocational and Technical Education Development Project (METGE)" which started with seven schools in seven provinces, was implemented between 1993 and 2003. In 1996, 57 schools in 33 provinces were involved in the project. After 2000, it was decided to extend the project to all provinces and to implement it in all vocational and technical education schools. The main objective of this project is to create a school structure that takes local needs into consideration and to improve the teaching system in line with these needs. In order to realize this aim, the development of modular education programs organized according to the needs, the establishment of vocational standards, raising students' awareness about the labour market and preparing the resources and school equipment to meet all these are other objectives of this project (Bolkol, 1999; Günceoğlu, 2003; Kavak, 1992). With the METGE Project, an understanding of education based on individual teaching which ensures the utilization of developing technology and can develop competence-based teaching programs was desired to be created and modular teaching studies were initiated accordingly (MEB, 2004).

MTEM: The Modernization of Vocational and Technical Education Project (MTEM), which is planned to be implemented between 2003-2007, has been prepared in order to improve the quality of the education of teachers who will take part in vocational and technical education. Within the scope of this project, field proficiencies of vocational course teachers were determined and 474 modular curriculums were developed based on these proficiencies and implemented in 14 vocational and technical education faculties since 2004-2005 academic year (MEB, 2009). In order to implement the training programs developed within the scope of this project, schools were also provided with hardware support. However, based on various researches, it was decided to close these faculties on the grounds that vocational and technical education faculties could not meet EU harmonization equivalence and there were problems in the employment of vocational teachers from these faculties and vocational and technical education faculties could not train personnel for the labour market. Following this decision, vocational education faculties were transformed into art and design faculties, technical education faculties were transformed into technology faculties and trade and tourism education faculties were turned into tourism faculties. For this reason, modular teaching materials developed within the scope of this project could not be put into practice and this project ended (Sezgin, \& Taşpınar, 2011). 
MEGEP/SVET: MEGEP / SVET (Strengthening the Vocational Education and Training System Project) which was planned to cover a five-year period and carried out between 2002-2007 the first six months of which was considered to be the initial period and the remaining 4.5 years was considered to be implementation period. Within the scope of this project, Analysis of Labour Market and Skills in Need was conducted in 31 provinces and information was obtained about the structure of Turkish labour market. A total of 576 professions were analysed and the occupational standards were determined through the studies conducted for sector and job analysis. Accordingly, training standards for 192 occupations in 42 fields were prepared. According to these standards, competency-based modular education programs were developed and 5189 modules were prepared for the execution of these programs. (MEB, 2010a). With this project, a new approach begun to be applied in which vocational and technical education would be preferred again with the participation of all parties in vocational and technical education, bridges would be established between education institutions and labour market, training programs based on national and international standards would be taken into consideration and supply-demand balance would be taken into consideration. (Altın, 2007; Sert, 2007; Gömleksiz, 2010). As of 2004-2005 academic year, a curriculum framework within the scope of this project has been begun to be implemented. According to this program, 9th grade courses were taken as common courses in general high schools as well as vocational and technical high schools. It was decided to increase the frequencies of vocational courses depending on the selected fields from 10th grade on. Within the context of this framework program, it was planned to give field diploma at the end of 12th grade and specialization certificate according to branches together with diploma (Altın, 2007). With this project, the modular teaching activities, which started with the METGE project before, have been transformed into the professional and technical implementation of the modular education programs throughout the country since the 2007-2008 academic year.

IKKMEP: Within the scope of the Human Resources Development through Vocational Education Project (İKMEP) implemented between 2008 and 2010, modular curriculum for 64 professions and information forms for 3600 modules were prepared with the participation of academicians, the Ministry of National Education representatives, field experts, sector representatives and representatives of non-governmental organizations. The aim of this project, which was carried out jointly by the Ministry of National Education Projects Coordination Centre and YÖK (Council of Higher Education), was to ensure the development of small and medium-sized enterprises in the East and Southeast with the contribution of qualified labour force, as well as cooperation between labour market vocational schools and vocational technical secondary education institutions. Improving the quality of vocational and technical education and ensuring the development of human resources were among the objectives of this project (Çolak, 2014). With this project implemented in 8 pilot provinces in Eastern and South-eastern Anatolia, occupational analyses and process analyses were conducted for the selected occupational fields and competency tables as well as module information forms were 
prepared based on these analyses. It was decided that the programs prepared based on these studies would be implemented in higher education institutions starting from the 2010-2011 academic year (Özdemir, \& Göktaş, 2012; Çolak 2014).

\section{RESULTS AND DISCUSSIONS}

In the light of all these, it can be seen that vocational and technical education institutions are widespread in Turkey and many programs are present in these institutions. In addition, national and international projects and collaborations are carried out for the development and reinforcement of vocational and technical education. It is seen that all these studies carried out in the process from pre-republic to the present regarding vocational and technical education are aimed at increasing the quality of human resources needed by the labour market and increasing the employment opportunities for the graduates of vocational and technical schools.

Obstacles to the development of vocational and technical education can be listed as; inadequate cooperation with the sector, inability to train individuals with the qualifications required by the industry, lack of training programs and vocational guidance, rigid and centralized structure of the system in spite of the efforts to make it more flexible, and lack of endeavour on creating awareness on vocational and technical education.

Based on these results, the following suggestions can be made: Efforts to raise awareness about vocational and technical institutions which are widespread in Turkey and involve many programs can be made. Thus, it can be ensured that vocational and technical education is a preferred field of education. In addition, as a result of all these improvement and development efforts, the employment opportunities of the graduates of vocational and technical education institutions can be expanded by making the right cooperation with the sector. Studies can be carried out in order to examine the effectiveness of the projects performed to develop and strengthen vocational and technical education. Finally, recent studies on technical and vocational education in other countries can be examined and researches on comparison of the practices in other countries can be carried out.

\section{References}

Adıgüzel, O. C., \& Berk, Ş. (2009). Mesleki ve teknik ortaöğretimde yeni arayışlar: yeterliğe dayalı modüler sistemin değerlendirilmesi. Yüzüncü Yıl Üniversitesi Eğitim Fakültesi Dergisi, 4(1), 220-236.

Akhun, İ. (1987). Okul-sanayi ortaklaşa (osanor) eğitimi. Hacettepe Üniversitesi Eğitim Fakültesi Dergisi, Özel Sayı, 2, 203-209.

Akyüz, Y. (2001). Türk eğitim tarihi. İstanbul: Alfa.

Alkan, C., Doğan, H., \& Sezgin, İ. (2001). Mesleki ve teknik eğitimin esasları. Ankara: Nobel. 
Altın, R. (2007). Mesleki eğitim sisteminde yeni eğilimler ve modüler sistem. Ankara: Mesut Matbaacılık.

Bolkol, N. (1999). Mesleki ve teknik eğitimde çağdaş bir yaklaşım "Metge" projesi. IV. Ulusal Eğitim Bilimleri Kongresi Bildirileri 2, Anadolu Üniversitesi Eğitim Fakültesi Yayın No: 51. Eskișehir, 418-430.

Celep, C. (2006). Türkiye'de mesleki ve teknik eğitim sorunları ve model önerisi. 1. Uluslararası Mesleki ve Teknik Eğitim Teknolojileri Kongresi 05-07 Eylül 2005, İstanbul. Basım: Marmara Üniversitesi, 2006.

Çolak, N. (2014). İkmep ve elektrik ön lisans programları. Elektronik Mesleki Gelişim ve Araştırma Dergisi (EJOIR), 2 (Özel sayı), 113-124.

Doğan, H. (1984). Okul sanayi ortaklaşa (OSANOR) eğitimi çalışmaları ve elde edilen sonuçlar. Ankara Üniversitesi Eğitim Bilimleri Fakültesi Dergisi, 16(1), 250-288.

Doğan, H. (1995). Okul-sanayi ilişkileri. Ankara: Bizim Büro Basımevi.

Eroğlu, G. (1999). Kız meslek lisesi el sanatları bölümü son sınıf öğrencilerinin okul-sanayi işbirliği kapsamında işletmelerde beceri eğitimi ile ilgili karşılaştıkları sorunlar, nedenleri ve çözüm yolları. Yayımlanmamış Yüksek Lisans Tezi, Gazi Üniversitesi, Ankara.

Gömleksiz, M. N. (2010). Mesleki ve teknik ortaöğretimde modüler öğretim uygulamasına ilişkin öğrenci görüşleri. E-Journal of New World Science Academy, 5(4), 2104-2122.

Günceoğlu, B. (2003). Kız teknik öğretim okulları meslek dersleri programlarının modüler öğretim yaklaşımına uygunluğunun öğretmen ve öğrenci görüşleri doğrultusunda tespiti: (Metge Projesi el sanatları teknolojisi alanı meslek dersleri program örneği).Yayımlanmamış yüksek lisans tezi, Gazi Üniversitesi, Ankara.

Herdman, E. A. (2006). Guidelines for conducting a literature review and presenting conference papers. Hemşirelikte Eğitim ve Araştırma Dergisi, 3(1), 2-4.

Kavak, Y. (1992). Meslek yüksekokulları iş hayatı ilişkileri. H.Ü. Eğitim Fakültesi Dergisi, 7, 95-115.

Kazu, İ. Y. (2002). Türk milli eğitim sisteminde mesleki ve teknik eğitim. Elazığ: Üniversite Kitabevi.

MEB. (2004). METGE Mesleki ve teknik eğitimi geliştirme projesi kapanış raporu. Ankara: MEB.

MEB (2006). 17. Milli Ĕ̆itim Şurass 11.03.2018 tarihinde https://ttkb.meb.gov.tr/meb iys dosyalar adresinden indirilmiştir.

MEB (2009). Projeler 09.09.2009 tarihinde www.projeler.meb.gov.tr adresinden indirilmiştir.

MEB (2010a). MEGEP 04.02.2010 tarihinde www.megep.meb.gov.tr adresinden indirilmiştir. 
MEB (2010b).

04.04.2010

http://earged.meb.gov.tr/urn/tr/pdf/mesleki_ve_teknik.pdf tarihinde indirilmiştir.

MEB (2010c). 18. Milli Eğitim Şurası 11.03.2018 tarihinde https://ttkb.meb.gov.tr/meb iys dosyalar adresinden indirilmiștir.

MEB (2012). Mesleki ve teknik eğitim çalıştayı. Ankara: MEB. Mesleki ve Teknik Eğitim Genel Müdürlüğü.

MEB. (2014). Türkiye Mesleki ve Teknik Eğitim Strateji Belgesi ve Eylem Planı 20142018. Ankara: MEB.

MEB (2018). Türkiye'de mesleki ve teknik eğitimin görünümü. Ankara: MEB Mesleki ve Teknik Eğitim Genel Müdürlüğü.

Mutlu, N., \& Akaya, G. (2006). Modüler program geliştirme. 1. Uluslararası Mesleki ve Teknik Eğitim Teknolojileri Kongresi 05-07 Eylül 2005, İstanbul. Basım: Marmara Üniversitesi.

Özçifçi, A., Göloğlu, C., \& Kadı, İ. (2004). Yükseköğretim öncesi mesleki ve teknik eğitim için öneriler, mesleki ve teknik eğitimde öğretmen eğitimi, Milli Eğitim Bakanlı̆̆ı: MTEP (Mesleki Eğitimin Modernizasyonu Projesi) Uluslararası Konferansı, 22-23 Ocak 2004, Ankara. 217-220.

Özdemir, D., \& Göktaş, Y. (2012). Meslek yüksekokullarında insan kaynaklarının mesleki eğitim yoluyla geliştirilmesi öğretim programının öğrencilerin akademik başarılarına etkisi: Erzincan Üniversitesi örneği. Yükseköğretim ve Bilim Dergisi, 2(2), 126-131.

Sert, Ö. (2007). Mesleki ve teknik ortaöğretim kurumlarında modüler öğretim sisteminin bilişim teknolojileri alanında uygulanması ve öğretmen, öğrenci açısından değerlendirilmesi Yayımlanmamış yüksek lisans tezi, Marmara Üniversitesi, İstanbul.

Sezgin, İ., \& Taşpnar, M. (2011). Mesleki ve teknik eğitime öğretmen yetiştirme. S. Aynal Kilimci (Editör). Türkiye'de Öğretmen Yetiştirme. Ankara: Pegem Akademi, ss 181208.

Şahin, İ., \& Fındık, T. (2008). Türkiye'de mesleki ve teknik eğitim: mevcut durum, sorunlar ve çözüm önerileri. Türkiye Sosyal Araştırmalar Dergisi, 12(3), 65-86.

Şahinkesen, A. (1985). Çıraklık eğitimi: Türk milli eğitim sistemindeki uygulamalar. Yayımlanmamış doktora tezi, Ankara Üniversitesi, Ankara.

Şahinkesen, A. (1992). Eğitimde ikili sistem. Ankara Üniversitesi Eğitim Bilimleri Fakültesi Dergisi, 25(2), 687-701.

TBMM. Hükümet programlarl. Retrieved from www.tbmm.gov.tr/kutuphane/e_kaynaklar_kutuphane_hukumetler.html

Kalkınma Bakanlığı (2013). 10. kalkınma planı. Retrieved from http://www.kalkinma.gov.tr

Yılmaz, F. (1996). Ülkemizde mesleki ve teknik eğitim. Eğitim ve Yaşam, 96, 18-23. 